\title{
Medical Hypotheses
}

\section{The Potential Role of Serum Ferritin in the Pathogenesis of Acquired Immune Deficiency Syndrome (AIDS)}

\section{J. M. WIGGINTON}

University of Michigan Medical School, 801 South Main St., Ann Arbor, Michigan 48104, USA

Abstract - Elevated serum ferritin levels have been observed in several disease states including various malignancies, inflammatory states, and the acquired immunodeficiency syndrome (AIDS). This discussion will examine the normal sequence of events in $T$ cell activation and proliferation, as well as the various defects in these events, and monocyte/macrophage and NK cell activity seen in AIDS patients. Further, the potential role of a serum suppressor factor as a contributor to the profound immunosuppression seen in AIDS will be discussed, as will evidence suggesting that ferritin may be this factor. A model is presented to explain mechanisms by which ferritin might suppress immune function and further studies to elaborate these mechanisms are proposed.

\section{Introduction}

Elevated serum ferritin levels have been noted in patients with various malignancies including Hodgkin's disease $(1,2)$, breast cancer $(3,4)$ and neuroblastoma (5), and more recently in patients with AIDS and AIDS-related complex (ARC) (6). This discussion will focus on the graded elevation of ferritin levels seen in patients with ARC and AIDS (6), and propose a model for the role of ferritin in the pathogenesis of AIDS.

The etiologic agent responsible for the acquired immune deficiency syndrome (AIDS) is the human $T$ lymphotropic virus type III (HTLV-III) $(7,8)$, now known as the human immunodeficiency virus (HIV). HIV binds to cells bearing the CD4 (T4) antigen on the cell surface, and in so doing is able to infect helper T lymphocytes $(9,10)$, monocyte/macrophages $(11,12)$, epidermal Langerhans cells $(13)$, and neurons and glial cells in the CNS $(9,14)$.

\section{T-cell activation}

Patients with AIDS have a variety of defects in immune function, which for the most part may be explained by depletion and/or functional disruption of helper/inducer $\mathrm{T}$ lymphocytes. Of particular concern here are the defects in $T$ lymphocyte, as well as natural killer (NK) and monocyte/macrophage function. Before considering the various defects, the normal sequence of events in $T$ cell activation will be discussed. Activation of $\mathrm{T}$ lymphocytes requires 
interaction of ligand with cell surface receptors and generation of intracellular signals, which in turn lead to the expression of activation markers (i.e. receptors for interleukin-2 and transferrin) (15-18), interleukin-2 (IL-2) production (19), and ultimately $\mathrm{T}$ cell proliferation Synthesis and expression of the interleukin-2 receptor (IL-2R) is an early event (20), while IL-2 production peaks within 24 hours of antigen stimulation (15) and transferrin receptor (Tf-R) expression peaks after 48 hours post-exposure (20). IL-2 regulates the expression of its own receptors as well as those for transferrin (Tf) $(18,21-23)$. IL-2 and transferrin receptor expression appears to be required for DNA synthesis and proliferation by activated T cells (18), as is the interaction of IL$2(19,24)$ and transferrin $(18,25)$ with these receptors. Monoclonal antibodies against the Tf$\mathrm{R}$ inhibit cell growth in vitro (26-29), and inhibit the generation of cytotoxic $T$ lymphocytes (30). Cytotoxic $T$ lymphocytes produce interferon- $\gamma$ (IFN- $\gamma$ ) in response to antigens or mitogens (38, $39)$, under the positive influence of $\operatorname{IL}-2(33,35)$. IL-2 is produced by helper $\mathrm{T}$ lymphocytes $(40$, 42).

\section{$T$ cell defects}

AIDS patients have several qualitative defects in the activation and proliferation of $T$ lymphocytes, in addition to the well documented lymphopenia and inversion of the helper/suppressor $\mathrm{T}$ lymphocyte ratio (36-43). These defects include decreased IL-2 production $(36,39,44)$ and IL-2R expression $(36,38,44)$, as well as decreased IFN- $\gamma$ production $(37,45$, 46) and cytotoxic $T$ cell activity (47). More general measures of $T$ lymphocyte function show decreased in vitro proliferation in response to mitogens $(36-39,41-43,48)$, antigens $(41,43$, $48)$, or alloantigens $(40,43)$, as well as decreased E-rosette formation $(42,43,48)$ and skin test reactivity $(43,48)$. Exogenous IL-2 can partially restore mitogen-induced lymphocyte proliferation (39) and cytotoxic $T$ cell activity (47) in vitro. In vivo, infusions of IL-2 cause a polyclonal expansion of $\mathrm{T}$ cells and IL-2R expression, but apparently have no impact on transferrin receptor expression or subsequent mitogeninduced $\mathrm{T}$ cell proliferation in vitro (49). IL-2 enhances IFN- $\gamma$ production by normal lymphocytes, but not those from AIDS patients (46). It appears then, that in addition to being decreased in total number, $T$ lymphocytes from AIDS patients have functional defects in both early and late stages of maturation. In that in vivo administration of IL-2 has no effect on transferrin receptor expression or $\mathrm{T}$ cell proliferation, and only partially restores $T$ cell proliferation when added in vitro, it would appear that there may be an extrinsic factor in vivo which suppresses late stages of $T$ cell activation. Further, although early stages of activation such as IL-2 production and IL-2R expression may be limited by an intrinsic defect of the infected $\mathrm{T}$ cell, it is possible that an extrinsic factor abrogates these as well.

\section{Monocyte/macrophage and NK cell defects}

The defects in $T$ cell activation and elaboration of lymphokines (IL-2 and IFN- $\gamma$ ), and the resultant reduction in $\mathrm{T}$ cell proliferation may secondarily limit dependent effector mechanisms, including monocyte/macrophage and natural kill cell activity. In normal individuals, IFN- $\gamma$ activates macroph?ges to kill microbial or tumor targets $(50,51)$. AIDS patients are seen to have diminished monocyte chemotaxis (52), and monocyte/macrophage killing of tumor targets $(53,54)$. Exogenous IFN- $\gamma$ can restore killing of both tumor (53) and microbial (37) targets by monocyte/macrophages from these patients. IFN- $\gamma$ augments the expression of class II major histocompatability complex (MHC) antigens on normal monocyte/macrophages (55). Not surprisingly, class II MHC expression is decreased on the monocyte/macrophage from AIDS patients, and can be restored to near normal levels by IFN- $\gamma$ treatment in vitro (56). Interaction of helper $T$ cells with antigenpresenting cells (APC), such as the monocyte/macrophage, is an MHC-II restricted process. Defects in helper $\mathrm{T}$ cell function then, may also reflect primary defects in the APC.

AIDS patients have decreased natural killer (NK) activity $(43,47)$. IL-2 $(46,57,58)$ and IFN$\gamma(46,59)$ enhance NK activity in both normal and AIDS patients, and do so via independent mechanisms (60). It is worth noting that NK activity appears to be important in the destruction of HIV-infected target cells (61), and interferon- $\gamma$ suppresses the replication of HIV in vitro (62). Given the deficits in $\mathrm{T}$ cell activation and IL-2/IFN- $\gamma$ production, the observed correlation between decreased interferon- $\gamma$ production and the progression of disease from ARC to AIDS (45), and the deficits in IL-2/IFN- $\gamma$ dependent effector functions, the question then remains, what is it that disrupts effective $T$ cell 
activation, lymphokine production and proliferation?

\section{A soluble suppressor}

Several studies have demonstrated circulating factor(s) in the serum of AIDS patients which can suppress $T$ cell activation and proliferation (63-67). This factor(s) suppresses mitogeninduced IL-2 production and IL-2R expression $(63,65)$ by normal lymphocytes, proliferation of IL-2 dependent cytotoxic $\mathrm{T}$ cell lines in response to IL-2 $(63,64)$, and proliferation of normal lymphocytes in response to mitogens, soluble antigens, or alloantigens in the mixed lymphocyte reaction (MLR) $(65,67)$. The factor has the following characteristics (66): not lymphotoxic, stable@pH 3-10 and up to, 60 ${ }^{\circ} \mathrm{C}$, inactivated (a) $100^{\circ} \mathrm{C}$, not ether extractable, not interferon, cortisol, IgG, IgM or an immune complex, not mediated by radiosensitive or $\mathrm{T} 8$ antigen-bearing suppressor cells, or increased prostaglandin $\mathrm{E}$ or decreased IL-1 production, does not reflect absence of a stimulatory or nutritive factor, inactivation of IL-2, inhibition of the IL-2 assay, or increased IL-2 turnover.

The suppressive effects of AIDS sera on normal lymphocytes persists after the cells have been washed, suggesting that the factor may be able to bind to receptors on lymphocytes (66). Pretreatment of IL-2R+ lymphoblasts with AIDS serum does not block binding of anti-IL2R monoclonal antibodies (63), so the suppressor apparently does not act by blocking the IL-2 receptor. Further, gel filtration of serum from AIDS patients shows that the inhibitory activity coelutes with the immunoglobulin fraction (63). Immunoglobulins have molecular weights ranging from 150000 daltons for IgG to 950000 daltons for IgM. Ferritin has a molecular weight of approximately 460000 dalton, and thus would be expected to coelute with the immunoglobulin fraction. It is proposed here that ferritin may be the circulating inhibitor.

\section{Ferritin as the suppressor?}

Several observations suggest that ferritin, particularly at the levels seen in AIDS patients, may be capable of suppressing $T$ lymphocyte function. Ferritin suppresses mitogen-induced $T$ lymphocyte blastogenesis (68-70). Although not examined specifically in $\mathrm{T}$ lymphocytes, ferritin and transferrin appear to utilize a common receptor-mediated endocytosis pathway in reticulocytes (71), and ferritin can disrupt transferrin endocytosis and reduce intracellular iron accumulation (72). As noted above, expression of the transferrin receptor (18) and interaction of transferrin with this receptor $(18,25)$ are required events in the activation and proliferation of $T$ cells. In fact, monoclonal antibodies directed against the transferrin receptor have been shown to inhibit mitogen-induced proliferation (73), the MLR (30), and the generation of cytotoxic $T$ cells $(30)$.

By abrogating the receptor-mediated endocytosis of transferrin by $T$ lymphocytes, ferritin may disrupt late stages of $T$ cell activation, and by limiting $T$ cell proliferation, the overall production of IL- 2 and IFN- $\gamma$ may be reduced.

\section{Conclusion}

As noted above, one study has demonstrated elevated serum ferritin levels in a small sample of AIDS and ARC patients (6). Several considerations, however, should be noted regarding this study. Ferritin may be nonspecifically elevated in inflammatory conditions (74), and various malignancies (1-4). The above study, however, uses only healthy heterosexuals as controls. More meaningful conclusions might be drawn if ferritin levels were also compared to those from patients with other conditions where ferritin is known to be elevated. Further, a mean serum ferritin for healthy heterosexual controls is reported as $160 \mu \mathrm{g} / \mathrm{dl}$ (i.e., $16000 \mathrm{ng} / \mathrm{ml}$ ), while most acknowledge the "normal" range to be $0-250 \mathrm{ng} / \mathrm{ml}$ (75). Given the extremely high values reported for normal controls, and the need for additional controls for comparison, it would be useful to more extensively explore the significance of elevated serum ferritin levels in AIDS patients. Preliminary examination here in 6 patients with CDC-defined AIDS has revealed a mean serum ferritin of $5028 \mathrm{ng} / \mathrm{ml}$ (R $2,072-12,174 \mathrm{ng} / \mathrm{ml})$.

No substantial proposal has been made regarding the significance of elevated ferritin levels in the pathogenesis of AIDS. It is proposed here that ferritin may disrupt functional processing of the transferrin (Tf) Tfreceptor complex and in so doing, limit $T$ cell activation and proliferation. By limiting $T$ cell proliferation, ferritin may indirectly cause reduction in the total lymphokine output of a given population of lymphocytes, and abrogate lymphokine-dependent immune function. Ferritin might directly limit IL-2 and IFN- $\gamma$ production 
as well. It would be useful to directly examine the impact of ferritin, at concentrations such as those seen in AIDS patients, on the processing of transferrin and production of IL-2 and IFN$\gamma$ by $\mathrm{T}$ lymphocytes. These studies are now in progress.

\section{References}

1. Jacobs A, Slater A, Whittaker J A. Serum ferritin concentration in untreated Hodgkins disease. $\mathrm{Br} \mathrm{J}$ Cancer 34: 162. 1976.

2. Schulof R S, Bockman R S, Garfalo J A, et al. Multivariate analysis of $T$ cell functional defects and circulating serum factors in Hodgkins disease. Cancer 48: $964,1981$.

3. Bezwoda W, Derman D, Bothwell T, MacPhil P, Levin J, DeMoore N. Significance of serum concentrations of carcinoembryonic antigen, ferritin and calcitonin in breast cancer. Cancer 48: 1623, 1981.

4. Hazard J T, Drysdale J W. Ferritinaemia in cancer. Nature 265: 755, 1977.

5. Hann H L, Evan A E. Cohen I J. Leitmeyer J E. Biologic differences between neuroblastoma stages IV-S and IV. Measurement of serum ferritin and E-rusette inhibition in 30 children. N Engl J Med 305: 425, 1981.

6. Gupta S. Imam A. Licorish K. Serum ferritin in acquired immune deficiency syndrome. $J$ Clin Lab Immunol 20: $11,1986$.

7. Gallo R C, Salahuddin S Z, Popovic M. Frequent detection and isolation of cytopathic retroviruses, HTLV-III from patients with AIDS and at risk for AIDS. Science 224: 500, 1984.

8. Barré-Sinoussi $F$, Chermann $J$ C, Rey F. Isolation of a T-lymphotropic retrovirus from a patient at risk for acquired immune deficiency syndrome, AIDS. Science 220: 868,1983

9. Maddon P J, Dalgleish A G, McDougal J S. The T4 gene encodes the AIDS virus receptor and is expressed in the immune system and the brain. Cell 47: 333, 1986.

10. Dalgleish A G, Beverley P C L, Clapham P R, Crawford D $H$, Greaves M F, Weiss R A. The CD4, T4 antigen is an essential component of the receptor for the AIDS retrovirus. Nature 312: 763, 1984.

11. Gartner S, Markovits P, Markovitz D M. The role of mononuclear phagocytes in HTLV-III/LAV infection. Science 233: 215, 1986.

12. Ho D D, Rota T R, Hirsch M S. Infection of monocyte/macrophages by human $\mathrm{T}$ lymphotropic virus type III. J Clin Invest 77: 1712, 1986.

13. Tschachler G, Groh V, Popovic M. Epidermal Langerhans cells - a target for HTLV-III/LAV infection. J Invest Dermatol 88: 233, 1987.

14. Funke I, Hahn A, Rieber E P. The cellular receptor, CD4 of the human immunodeficiency virus is expressed on neurons and glial cells in human brain. J Exp Mcd 165: $1230,1987$.

15. Goronzy J, Weyand C, Imboden J, Manger B, Gathman $C G$. Heterogeneity of signal requirements in $T$ cell activation within a panel of human proliferative $T$ cell clones. J Immunol 138: 3087, 1987

16. Hemler $M D$, Breener $M B$, Mcl ean I $M$, Strominger J L. Antigen stimulation regulates the level of expression of IL-2-receptors on human T-cells. Proc Natl Acad Sci USA $81: 2172,1984$.

17. Cantrell D A, Smith K A. Transient expression of interleukin-2 receptors: consequences for $\mathrm{T}$ cell growth. J Exp Med 158: 1895, 1983

18. Neckers L M, Cossman J. Transferrin receptor induction is required for DNA synthesis and cell division and is regulated by interleukin. 2. Proc Natl Acad Sci USA $80: 3494,1983$.

19. SmithK A. T-cell growth factor. Immunol Rev 51: 337 , 1980.

20. Kronke M, Leonard W J, Depper J M, Greene W C. Sequential expression of genes involved in human $T$ lymphocyte growth and differentiation. J Exp Med 161: $1593,1985$.

21. Smith K A, Cantrell D A. Interleukin 2 regulates its own receptors. Proc Natl Acad Sci USA 82: 864, 1985.

22. Reem $G$, Yeh $\mathbf{N}$ H. Interleukin 2 regulates expression of its receptor and synthesis of gamma interferon by human T lymphocytes. Science 225: 429, 1984.

23. Welte $K$, Andreeff $\mathbf{M}$, Platzer $\mathbf{E}$, et al. Interleukin 2 regulates the expression of Tac antigen on peripheral blood T lymphocytes. J Exp Med 160: 1390, 1984.

24. Farrar-J J, Benjamin W R, Hilfiker M L, Howard M, Farrar W L, FullerFarrar J. The biochemistry, biology and role of interleukin-2 in the induction of cytotoxic $T$ cell and antibody-forming $B$ cell responses. Immunol Rev 63: 129.

25. Lerrick $\mathbf{J} \mathbf{W}$, Cresswell $P$. Modulation of cell surface iron transferrin receptors by cellular density and state of activation. J Supramol Struct 11: 579, 1979.

26. Trowbridge I. Lesley J, Schulte R. Murine cell surface transferrin receptor: studies with an anti-receptor monoclonal antibody. J Cell Physiol 112: 403, 1982.

27. Takei $\mathbf{F}$. Two surface antigens expressed on proliferating mouse $\mathrm{T}$ lymphocytes defined by rat monoclonal antibodies. J Immunol 130: 2794, 1983.

28. Van Agthoven A, Goridis C, Naquet P, Pierres A, Pierres M. Structural characteristics of the mouse transferrin receptor. Eur J Biochem 140: 433, 1984.

29. Lesley J, Schulte R. Inhibition of cell growth by monoclonal anti-transferrin receptor antibodies. Mol Cell Biol 5: $1814,1985$.

30. Rammensee H, Lesley J, Trowbridge I, Bevan M. Antibodies against the transferrin receptor block the induction of cytotoxic $\mathrm{T}$ lymphocyte. A new method for antigen-specific negative selection in vitro, Eur J Immunol 15; 687, 1985

31. Klein J R, Raulet D H, Pasternack M S, Bevan M J. Cytotoxic $\mathrm{T}$ lymphocytes produce immune interferon in response to antigen or mitogen. J Exp Med 155: 1198. 1982.

32. Matsuyama M, Sugamura K, Kawade $Y$, Hinuma $Y$. Production of immune interferon by human cytotoxic $T$ cell clones. J Immunol 129: 450, 1982.

33. Torres B A, Farrar W L, Johnson H M. Interleukin 2 regulates immune interferon, IFN- $\gamma$ production by normal and suppressor cell cultures. J Immunol 128: $2217,1982$.

34. Farrar W L, Johnson H M, Farrar J J. Regulation of the production of immune interferon and cytotoxic $T$ lymphocytes by interleukin 2. J Immunol 126: 1120, 1981.

35. Mizuochi T. Ono S. Malek T R, Singer A. Characterization of two distinct primary $T$ cell populations that 
secrete interleukin 2 upon recognition of class I or class II major histocompatability antigens. J Exp Med 163: 603, 1986.

36. Gupta S. Study of activated T cells in man. Il Interleukin 2 receptor and transferrin receptor expression on $T$ cells and production of interleukin 2 in patients with acquired immuno deficiency syndrome, AIDS and AIDS-related complex. Clin Immunol Immunopathol 38: 93, 1986.

37. Murray H W, Rubin B Y, Masur H. Roberts R B. Impaired production of lymphokines and immune, gamma interferon in the acquired immunodeficiency syndrome. N Engl J Med 310: 883, 1984.

38. Prince H E, Kermani-Arab V. Fahey J L. Depressed interleukin 2 receptor expression in acquired immune deficiency and lymphadenopathy syndromes. J Immunol 133: 1313, 1984

39. Ciobanu N, Welte K, Kruger G, et al. Defective T-cell response to $\mathrm{PHA}$ and mitogenic monoclonal antibodies in male homosexuals with acquired immunodeficiency syndrome and its in vitro connection by interleukin 2 . J Clin Immunol 3: 332, 1983.

40. Gupta S, Safai B. Deficient autologous mixed lymphocyte reaction in Kaposi's sarcoma associated with deficiency of Leu-3+ responder $\mathrm{T}$ cells. J Clin Invest 71: 296,983

41. Schroff R W, Gottiieb M S, Prince H E, Chai L L. Fahey J L. Immunulugic studies of homosexual men with immunodeficiency and Kaposi's sarcoma. Clin Immunol Immunopathol 27: 300, 1983.

42. Gottlicb M S, Schroff R, Schanker II M, Weisman J D. Fan P T, Wolf R A, Saxon A. Pneumocystis carinii pneumonia and mucosal candidiasis in previously healthy homosexual men: evidence of a new acquired cellular immunodeficiency. N Engl J Med 305: 1425, 1981.

43. Siegal F P. Lopez E, Hammer G S, et al. Severe acquired immunodeficiency in male homosexuals, manifested by chronic perianal ulcerative herpes simplex lesions. N Engl J Med 305: 1439, 1981.

44. Tsang K Y. Fudenberg H H, Galbraith G M P, Donnelly R P, Bishop L R, Koopman W R. Partial restoration of impaired interleukin-2 production and Tac antigen expression in AIDS patients by isoprinosine treatment in vitro. J Clin Invest 75: 1538, 1985

45. Huygen K, Mascart-Lemone F, Ctan S, Van DePerre P, Henrivaux P. DeLey M. Clumeck N. Analysis of the interferon system in African patients with acquired immunodeficiency syndrome. Eur J Clin Microbiol 4: 304. 1985.

46. Rook A H. Hooks J J, Quinnan G V, et al. Interleukin 2 enhances the natural killer cell activity of acquired immunodeficiency syndrome patients through a gammainterferon-independent mechanism. J Immunol 134: 1503, 1985.

47. Rook R H, Masur H, Lane H C. et al. Interleukin-2 enhances the depressed natural killer and cytomegalovines-specific cytotoxic activities of lymphocytes from patients with the acquired immunodeficiency syndrome. J Clin Invest 72: 398, 1983.

48. Masur H, Michelis M A, Greene J B, et al. An outbreak of community-acquired $P$. carinii pneumonia: initial manifestation of cellular immune dysfunction. N Engl $\mathrm{J}$ Med 305: 1431, 1982.

49. Kolitz J E. Welte K, Wong G Y, et al. Expansion of activated $\mathrm{T}$-lymphocytes in patients treated with recombinant interleukin 2. J Biol Resp Mod 6: 412, 1987.
50. Le J, Prensky W, Yip Y K, et al. Activation of human monocyte cytotoxicity by natural and rccombinant immune interferon. J Immunol 131: 2821, 1983.

51. Pace J L, Russell S W, Schreiber R D, Altman A, Katz $\mathrm{D} H$. Macrophage activation: priming activity from a $\mathrm{T}$ cell hybridoma is attributable to interferon- $\gamma$. Proc Natl Acad Sci USA 80: 3782, 1983.

52. Smith P D, Ohura $K$, Masur $H$. Monocyte function in the acquired immune deficiency syndrome. Clin Res 32: $3528,1984$.

53. Kleinerman E S. Ceccorulli L M. Zwelling L A. Twilley T, Herberman R B, Jacob J, Gelmann E P. Activation of monocyte-medicated tumoricidal activity in patients with acquired immunodeficiency syndrome. J Clin Oncol 3: $1005,1985$.

54. Smith P, Ohura K, Masur H, Lane H C. Fauci A S. Wahl S M. Monocyte function in the acquired immune deficiency syndrome: defective chemotaxis. J Clin Invest 74: 2121,1984

55. Basham T, Merigan T C. Recombinant interferon- $\gamma$ increases HLA-DR synthesis and expression. $J$ Immunol 130: $1492,1983$.

56. Heagy W, Kelley V E, Strom T B, Mayer K, Shapiro $H$ M, Mandel R, Finberg R. Decreased expression of human class II antigens on monocytes from patients with acquired immune deficiency syndrome. Increased expression with interferon- $\gamma$. J Clin Invest 74: 2089, 1984

57. Flomemberg N, Welte K, Mertelsmann R. Interleukin 2 dependent natural killer, NK cell lines from patients with primary $T$ cell immunodeficiencies. J Immunol 130: $2635,1983$.

58. Henncy C S, Kuribayashi K, Kern D E, Gillis S. Interleukin-2 augments natural killer activity. Nature 291: 335,1981

59. Okabe M. Gomi K, Morimoto M. Nakamizo N. The different effects of recombinant human interferon- $\gamma$ and recombinant human interferon- $\beta$ on the activation of natural killer cells. Jpn J Cancer Res 76: 608, 1985.

60. Sayers $T$, Mason A, Ortaldo J. Regulation of human natural killer cell activity by interferon- $\gamma$ : lack of a role in interleukin 2-mediated augmentation. J Immunol 136: $2176,1986$.

61. Ruscetti F, Mikovits J, Kalyanaraman V, et al. Arialysis of effector mechanisms against HTLV-I- and HTLVIII/LAV-infected lymphoid cells. J Immunol 136: 3619 , 1986.

62. Nakashima $H$, Yoshida $T$, Harada $S$, Yamamoto $N$. Recombinant human interferon gamma suppresses HTLV-III replication in vitro. In J Cancer 38: 433. 1986.

63. Donnelly R P, LaVia M F, Tsang K Y. Humoralmediated suppression of interleukin 2-dependent target cell proliferation in acquired immune deficiency syndrome, AIDS: interference with normal IL-2 receptor expression. Clin Exp Immunol 68: 488 . 1987.

64. Donnelly R P , Tsang K Y, Galbraith G M P, Wallace $J$ P. Inhibition of interleukin 2-induced $T$ cell proliferation by sera from patients with the acquired immune deficiency syndrome. J Clin Immunol 6: 92, 1986.

65. Farmer J L, Gottlieb A A, Nishihara T. Inhibition of interleukin-2 production and expression of the interleukin-2 receptor by plasma from acquired immune deficiency syndrome patients. Clin Immunol Immunopathol 38: 235. 1986.

66. Siegel J P. Djeu J Y, Stocks N I, Masur H, Gelmann E, 
Quinnan G V Jr. Sera from patients with the acquired immunodeficiency syndrome inhibit production of interleukine by normal lymphocytes. J Clin Invest 75: 1957, 1985.

67. Cunningham-Rundles S, Michelis M A, Masur H. Serum suppression of lymphocyte activation in vitro in acquired immunodeficiency disease. J Clin Immunol 3: 156, 1983.

68. Matzner Y. Hershko C. Polliach A, Konijn A, Izak G. Suppressive effect of ferritin on in vitro lymphocyte function. Br J Haematol 42: 345, 1979.

69. Sugiyama Y, Takao H, Saji S, Sakata K. Studies on adoptive immunotherapy using recombinant interleukin 2. Gan To Kagaku Ryoho 13: 1307, 1986.

70. Chernovskaia E M, Polevaia E B, Tuzhikova N K. Relation of blood serum ferritin and ferritin-bearing lymphocytes in breast cancer. Med Radiol, Mosk 31: 15, 1986.

71. Blight G D, Morgan E H. Receptor-mediated endocy- tosis of transferrin and ferritin by guinea-pig reticulocytes. Uptake by a common endocytic pathway. Eur J Cell Biol 43: $260,1987$.

72. Blight G D, Morgan E H. Transferrin and ferritin endocytosis and recycling in guinea-pig reticulocytes. Binchem Biophys Acta 929: 18, 1987.

73. Brock J, Maniou-Fowler 'T. Webster L. Evidence that transferrin may function exclusively as an iron donor in promoting lymphocyte proliferation. Immunology 57: 105, 1986.

74. Summers $M$, White $G$, Jacobs A. Ferritin synthesis in lymphocytes, polymorphs, and monocytes. $\mathrm{Br} \mathrm{J}$. Haematol 30: 425, 1975.

75. Appendix A2 in Harrison's Principles of Internal Medicine. 11th ed. (E Braunwald, K J Isselbacher, R G Petersdorf, J D Wilson, J B Martin, A S Fauci, eds) McGraw-Hill, New York, 1987. 